\title{
Medicine, Race and the General Good: The Career of Thomas N G Te Water (1857-1926), South African Doctor and Medical Politician
}

\begin{abstract}
ANNE DIGBY*
In a recent lecture on the Oxford Dictionary of Biography, Keith Thomas argued that an anti-heroic and democratizing age had subverted the "Great Man" tradition of biography, but that a modern biography, with its distinctive blend of art and science, possessed the interest of looking at individual human agency and the constraints under which it operated, whilst its sharp focus on a noteworthy individual made it accessible for the general as well as the academic reader. ${ }^{1}$ A decade before this, a resurgence of interest in the biographical approach within the history of science (including medicine) had been detected by Michael Shortland and Richard Yeo. This approach facilitated the integration of cultural and institutional narratives, enabled the inclusion of much greater detail than in general history and, through discussion of the qualities of the individual practitioner, it also permitted an analysis of the possibilities or constraints of the subject's historical surroundings, so elucidating the character of the wider scientific/medical world of the past. ${ }^{2}$ Within an interwar British context, Roger Cooter has shown that the doctor as medical politician has been a neglected topic, but one that can well repay the attention of the medical historian, as in his excellent medical group biography. He argued that an attempt to protect the medical profession against legislative interference in interwar Britain had limited success because of the constraints of the time: the problems of locating able and willing candidates, or finding viable constituencies. Once elected, these MPs had a tendency to represent their constituency or follow their conscience rather than to advance professional interests, whilst elevation to a ministerial position meant that the political realities of office constrained them. ${ }^{3}$ For colonial doctors, Roy McLeod has judged that although "biography illuminates the collective" yet colonial medical biography has hardly begun. ${ }^{4}$ This article is a response both to this perceived lack of colonial material and to the rich potential of a biographical approach through a discussion of Thomas N G Te Water's dual identity as doctor and politician in the Cape.

(C) Anne Digby 2007

*Prof. Anne Digby, School of Humanities, Centre for Health, Medicine and Society, Oxford Brookes University, Gipsy Lane Campus, Headington, Oxford OX3 0BP, UK.

I appreciate the financial assistance given for this research by the Wellcome Trust, the generosity of Elizabeth van Heyningen in allowing me to use her data set of Cape doctors, and the helpful comments of Howard Phillips, John Stewart and three anonymous referees.

${ }^{1} \mathrm{~K}$ Thomas, Changing conceptions of national

Leslie Stephen Memorial Lecture, Cambridge University Press, 2005.

${ }^{2}$ Editorial 'Introduction' to M Shortland and R Yeo (eds), Telling lives in science: essays on scientific biography, Cambridge University Press, 1996, pp. 6, 15, 29, 31.

${ }^{3} \mathrm{R} J$ Cooter, 'The rise and decline of the medical member: doctors and parliament in Edwardian and interwar Britain', Bull. Hist. Med., 2004, 78 (1): 59_ 107, on pp. 85-6, 93, 96-7.

${ }^{4} \mathrm{R}$ Macleod, 'Colonial doctors and national myths: on telling lives in Australian medical biography', in M Sutphen and B Andrews (eds), Medicine and colonial
\end{abstract} biography: the Oxford DNB in historical perspective, 


\section{Anne Digby}

Te Water's career was distinctively South African yet at key points British influence was significant, as in his initial medical education in Edinburgh; an emphasis on reforms in public health in the Cape Colony's Colonial Department that helped shape Te Water's interventionism first as a local district surgeon and later as Colonial Secretary; and in the imperialistic context of the South African War of 1899 to 1902 that was the setting for the end of his political career. Thomas Te Water's entry in the Dictionary of South African Biography focuses on his political career, with only an uninformative sentence on his work as a doctor, where he is described as having "established a large practice in GraaffReinet". 5 This does less than justice not only to his medical contribution but to the way in which his public service was itself informed by his medical interests. Very unusually for a South African doctor, some of his clinical case books together with financial accounts and correspondence with patients have survived to enable a partial reconstruction of his medical practice and its relationship to his political activities to be attempted. The article first discusses Te Water's private practice before analysing the doctor's increasing role in public health, both locally and nationally, and finally discussing his contribution to one of the most significant enquiries in South African medical history-the Tuberculosis Commission of 1912-14.

Although there is a growing amount of published material on South African medicine, this historiography has had a strong bias towards public health, notably in substantive research publications on tuberculosis, silicosis, plague, or syphilis. ${ }^{6}$ There is also biographical work on a few individual doctors including three of Te Water's contemporaries (in a brief article on the Transvaal's John Mehliss, a full-length biography of the Free State's Henry Taylor, and what the author termed a "pseudoautobiography" of the Eastern Cape's W G Atherstone), together with a scholarly edited correspondence of the Cape's first medical woman, Jane Waterston, as well as biographies of the well-known doctor turned politician, Dr Leander Starr Jameson, a premier of the Cape from 1904 to $1908 .^{7}$ More recently, there has been a substantive social history of the Cape doctor but this contains little on the clinical work of private practitioners when

identity, London, Routledge, 2003, pp. 125-42, on pp. $136,126$.

${ }^{5}$ Dictionary of South African Biography (hereafter $D S A B), 5$ vols, Pretoria, Human Sciences Research Council, 1987, vol. 5, pp. 766-7.

${ }^{6} \mathrm{M}$ W Swanson, 'The sanitation syndrome: bubonic plague and urban native policy in the Cape Colony, 1900-1909', J. Afr. Hist., 1977, 18: 387-410; E van Heyningen, 'Agents of empire: the medical profession in the Cape Colony, 1880-1910', Med.Hist., 1989, 33: 450-71; E van Heyningen, 'Public health and society in Cape Town, 1880-1910', PhD thesis, University of Cape Town, 1989; R M Packard, White plague, black labor: tuberculosis and the political economy of health and disease in South Africa, Pietermaritzburg, University of Natal Press, 1990; E Katz, The white death: silicosis on the Witwatersrand gold mines, 1886-1910, Johannesburg, University of Witwatersand Press,
1994; K Jochelson, The colour of disease: syphilis and racism in South Africa, 1880-1950, London, Palgrave, 2001.

${ }^{7} \mathrm{~J}$ T B Collins, 'John Max Mehliss, M.D., a Transvaal medical pioneer', S. Afr. med. J., 29 June 1983: 14-16; P Hadley (ed.), Doctor to Basuto, Boer and Briton, 1877-1906: memoirs of Dr Henry Taylor, Cape Town, David Philip, 1972; N Mathie, Man of many facets: $D r W . G$. Atherstone, 1814-1898, pseudo-autobiography, 3 vols, Grahamstown, Grocott \& Sherry, 1997-8; L Bean and E van Heyningen (eds), The letters of Jane Elizabeth Waterston 1866-1905, Cape Town, Van Riebeeck Society, 1983; I Colvin, The life of Jameson, London, E Arnold, 1922;

J Carruthers (ed.), The Jameson raid: $a$ centennial retrospective, Johannesburg, Brenthurst Press, 1996. 


\section{The Career of Thomas N G Te Water (1857-1926)}

compared to the extensive discussion of their public roles. ${ }^{8}$ This article aims to supplement this historiography by looking at Te Water's private practice as well as his work in public health.

A useful contemporary comparison for Te Water's South African career is provided by a collective biography of physician-legislators in France's early Third Republic by J D Ellis. This shows professional trajectories from membership of rural elites to political participation at the national level and with successful local medical practice stimulating political consciousness. French physician-legislators furthered medical authority through their activity as law makers, where they were prominent in enacting a remarkable twentyeight major pieces of health legislation between 1871 and $1914 .^{9}$ A similar interplay of medicine and politics was conspicuous in Te Water's career. The professional expertise so evident in Te Water's private practice was of use to him in wider health care reform when, with opportune timing, he moved from his rural general practice in Graaff-Reinet to participate in politics in the colonial capital of Cape Town where he assumed a position at the leading edge of modernization in the Cape Colony. ${ }^{10}$ As a medical politician Te Water served in the Sprigg and Schreiner ministries from 1896 to 1900 within a historical context of an advancing frontier of public intervention in medical affairs. During the last two decades of the nineteenth century, there were no less than nineteen pieces of legislation dealing with medicine, together with the creation of a colonial Department of Public Health and the appointment of a Colonial Medical Officer of Health. As Elizabeth van Heyningen has noted, South African doctors of Te Water's generation saw their "medical mission in political terms" and thought that "the work of the profession should be performed on a wider stage". ${ }^{11}$ Doctors, exemplified here by Te Water, were successful in achieving considerable influence on public affairs, although this occurred rather later than in France.

\section{The Context of Medical Practice}

Thomas Te Water spent much of his life in Graaff-Reinet, a regional centre for the inland Midland region of the Cape Colony, some four hundred miles north-east of the colonial capital of Cape Town. (See map of South Africa in the 1890s.) The Cape Colony was the largest of four white settler states in South Africa, having by 1904 a white population of 579,000 that exceeded the combined total of the other three territories of Natal, Orange Free State and the South African Republic. The Cape had a population of 2,408,000 of whom 24 per cent were white, 58 per cent African and 16 per cent "coloured" or mixed race. ${ }^{12}$ This racial composition was highly relevant to any assessment of Te Water's medical contribution. Te Water was a member of a well-known Graaff-Reinet family and hence possessed useful contacts with which to forge a career. Having received British

\footnotetext{
${ }^{8} \mathrm{H}$ Deacon, H Phillips and E van Heyningen (eds), The Cape doctor in the nineteenth century: a social history, Amsterdam, Rodopi, 2004.

${ }^{9} \mathrm{~J}$ D Ellis, The physician-legislators of France: medicine and politics in the early Third Republic, 1870-1914, Cambridge University Press, 1990, pp. 3, 10, 79, 239-41.
}

\footnotetext{
${ }^{10} \mathrm{~N}$ Worden, E van Heyningen, V Bickford-Smith, Cape Town: the making of a city, Cape Town, David Philip, 1997, p. 223.

${ }^{11}$ Van Heyningen, 'Agents of empire', op. cit., note 6 above, pp. 464-5.

${ }^{12}$ A Digby, Diversity and division in medicine: healthcare in South Africa from the 1800s, Oxford and
} 


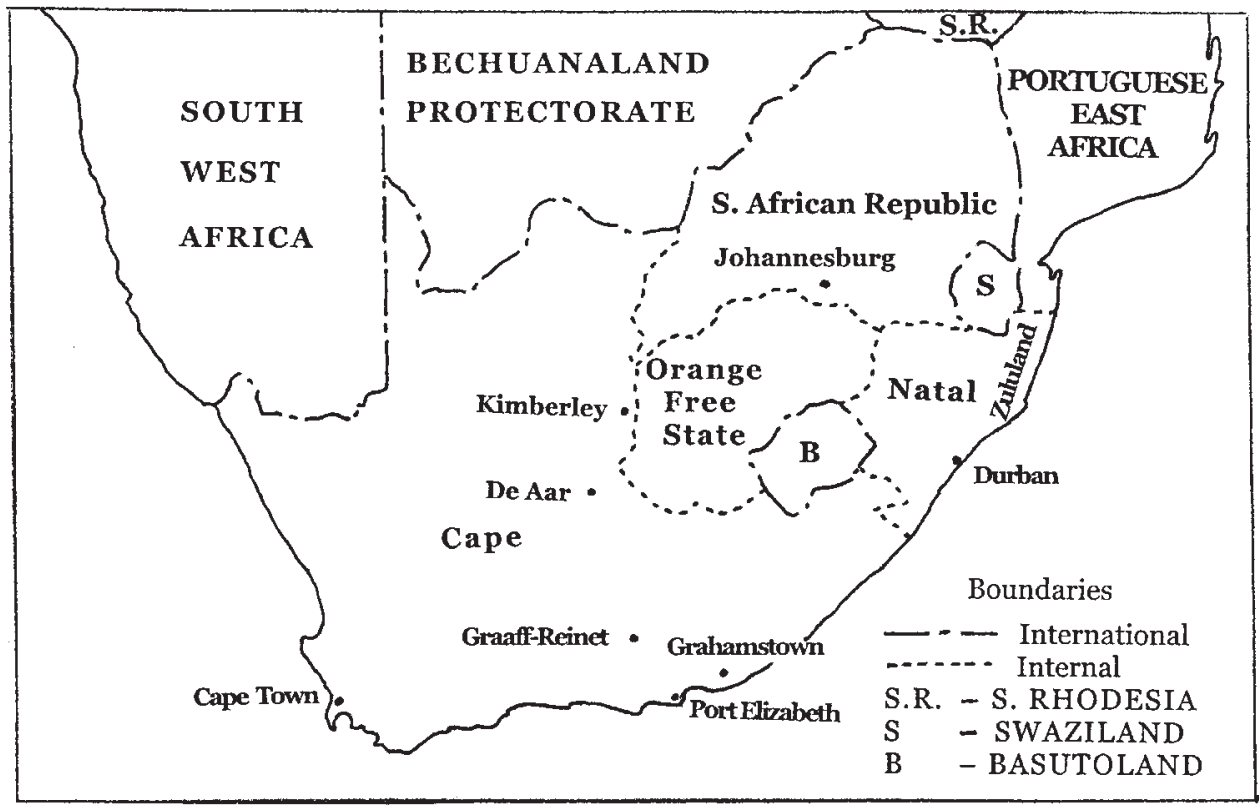

South Africa in the 1890 s

qualification as a doctor but also benefiting from post-graduate training in Europe, he was exceptionally well qualified for a South African general practitioner of his generation. After his initial medical training at Edinburgh, where he qualified in 1879, he had two years of post-graduate work in Berlin, Vienna, Strasbourg and London, before receiving an MD in $1881 .^{13}$

Varied backgrounds and training amongst nineteenth-century Cape doctors exemplified the diverse origins and composition of the white inhabitants of the Cape of Good Hope, a colony occupied by the British in 1806, and formally ceded by the Dutch in 1814 . The Cape medical profession was distinctive but not unique in being fashioned by more than one tradition-in this case both by the Dutch and British metropoles. ${ }^{14}$ As Howard Phillips has shown, more than nine out of ten of the white doctors licensed in the Cape between 1810 and 1910 had qualified in Britain. Te Water's choice of a Scottish university was typical of members of his generation, since, although some Afrikaners in the early and mid-nineteenth century had gone to Holland or Germany, by the later nineteenth century most chose Britain. ${ }^{15}$ It was only from 1922 that the Cape had its first locally-trained medical

Frankfurt, Peter Lang, 2006, table 1.2; C H Feinstein, An economic history of South Africa: conquest, discrimination and development, Cambridge University Press, 2005, table A1.1.

${ }^{13}$ Thomas N G Te Water, MB, CM Edinburgh, 1879; MD, London, 1881.

\footnotetext{
${ }^{14}$ Harriet Deacon, 'Introduction: the Cape doctor in the nineteenth century', in Deacon, et al. (eds), op. cit., note 8 above, pp. 17-43, on p. 21.

${ }^{15} \mathrm{H}$ Phillips, 'Home taught for abroad: the training of the Cape doctor, 1807-1910', in H Deacon, et al. (eds), op. cit., note 8 above, pp. 105-132.
} 
graduates. (This was unlike the situation in Canada, India or Australia where greater selfconfidence had resulted in much earlier medical schools. ${ }^{16}$ ) Set up in Graaff-Reinet in 1881, Te Water's practice was shaped to a large extent by its Cape context—notably by a crowded medical market, a mix of public and private practice, the wide geographical extent of a rural practice, and by a segregated society's racial divisions that helped shape his patient constituency. But his practice also reflected his initial training and therefore showed similarities with contemporary general practice in Britain. Assumptions about the superiority of British medicine and culture and the need to advance it were common, although a wider sense of a civilized Cape identity gradually became dominant among both English and Afrikaner practitioners. ${ }^{17}$

Nineteenth-century urban doctors, especially those in Cape Town, had a privileged position relative to their rural counterparts. ${ }^{18}$ Few chose to practise in a country location as was indicated by the first Union Census of 1911, which showed that as many as 87 per cent of South African doctors settled in towns, and that in the Cape Province as few as one in ten doctors had country practices. ${ }^{19}$ This disproportionate bias towards urban practice was also found in other colonial territories, such as Victoria in Australia. ${ }^{20}$ Few inland towns within the Cape Colony had the appearance of sufficient wealth to attract a cluster of doctors, so that Graaff-Reinet-with its economy based on the prime sheep-rearing surrounding district-became something of a medical "honey-pot". The first "western" qualified doctor in the town discernible in professional records was the colonial-born Gysbert Maasdorp, who came in 1843, having qualified in Leyden four years earlier, and who then practised in the town until his death in $1888 .^{21}$ From the 1850 s the town and its surrounding Midland area was targeted by a group of German-Jewish doctors who hoped to find patients amongst settlers from the same background already inhabiting the region. So Abraham Lilienfeld arrived in 1852, Adolf Arenhold in 1860, and Moritz Alsberg in $1864 .{ }^{22}$ Revealingly, two of them moved on to establish more viable practices elsewhere. It was not until the late 1870s and early 1880s that the British-trained Thomas Te Water, George Hislop, and W H L Welchman came to practise in the growing town. All were sufficiently successful professionally to enable them to stay. That Te Water came from a powerful dynasty in Graaff-Reinet no doubt attracted him back to the town, and also enabled him to have a head start in developing a successful practice through exploiting family networks.

The plentiful practice openings of the 1870 s dwindled as more doctors qualified, so that by 1900 the Cape was perceived as being "as crowded now as it was empty then". ${ }^{23}$ An overcrowded profession operating within a notably open pluralistic medical

\footnotetext{
${ }^{16}$ Deacon, op. cit., note 14 above, above, p. 23.

${ }^{17} \mathrm{See}$, for example, the presidential addresses to the first and second medical congresses in South Africa, in BMA presidential addresses, 1888-1908, Cape Town, BMA, 1908, pp. 2-4.

${ }^{18}$ H J Deacon, "Cape Town and "country" doctors in the Cape Colony during the first half of the nineteenth century', Soc. Hist. Med., 1997, 10: $25-52$.

${ }^{19}$ Union government papers, UG 32-912, Union Census, 1911, part V, occupations, pp. 706-7.
}

\footnotetext{
${ }^{20} \mathrm{~T}$ S Pensabene, The rise of the medical practitioner in Victoria, Canberra, Australian National University, 1980, pp. 74, 80.

${ }^{21}$ Database from Cape Medical Council records of licensing for medical practice compiled by Elizabeth van Heyningen.

${ }^{22} \mathrm{E} H$ Burrows, A history of medicine in South Africa, Cape Town, A A Balkema, 1958, pp. 187-8, 185-6.

${ }^{23}$ Dr C F K Murray, 'Presidential address', S. Afr. med. Rec., 1910, 8: 260-1; A Digby, “ “A medical El
} 
market could result in undesirable undercutting of a colleague's fees, as well as in failed practices and notable professional mobility. ${ }^{24}$ Of the eight doctors-seven trained in Britain and one in Germany-who first appeared in directories as practising in GraaffReinet during the period from 1889 to 1902, only Charles Hudson survived these very competitive conditions, whilst the rest moved on to apparently more promising territory opened up by an advancing frontier. ${ }^{25}$ In addition to these eight doctors, the correspondence of Te Water with his patients revealed that several other doctors practised in the town, but none survived professionally for long enough to record their name in medical registers or directories. In contrast to Britain, where a comfortable medical income could be built up during a medical lifetime, and a practice then sold to finance retirement, relatively few South African practices were marketable because so much depended on the fickle "goodwill" of patients. ${ }^{26}$ Such financial insecurity also contributed to conspicuous professional mobility and, in this respect, South Africa was similar to India, Australia or New Zealand. ${ }^{27}$

\section{Private Practice}

Te Water's general practice included both a surgical and a medical dimension, as was then common among biomedical practitioners. His first case book was characteristic of a young and inexperienced doctor, whose light caseload allowed him to compile detailed records. It showed careful clinical case histories and, under the heading of "Complaints", began with a thorough set of observations of his patient's physical state including comments on pulse, respiration rate, heartbeat, and temperature. He paid especial attention to the chest where he employed auscultation and palpation. This was probably connected to the fact that from the 1870s Graaff-Reinet had developed into a health resort, whose dry air and sunshine was recommended to immigrants suffering from tuberculosis, with a consequent spread of tubercular disease to local South Africans. ${ }^{28}$ In addition he recorded observations on the patient's pain, appetite, sleep patterns, and perspiration, as well as whether there was a furred tongue, or if there was constipation. Unusually, Te Water made notes on the feelings or attitudes of his patients in recording, for example, whether there was a state of anxiety. He made annotations of whether any other doctor had seen the patient, and if their therapy had worked, before making his own "provisional diagnosis" and working out a "treatment" including an individual prescription for medication. The later progress of the case was monitored, and observations recorded, such as "visited patient who looks a great deal better". ${ }^{29}$ From these early case notes it is clear that Te

\footnotetext{
Dorado?" Colonial medical incomes and practice at the Cape', Soc.Hist.Med., 1995, 8: 463-79, on pp. 464-71.

${ }^{24}$ A Digby, 'Making a medical living: the economics of medical practice in the Cape, c.1860-1910', in Deacon, et al. (eds), op. cit., note 8 above, pp. 249-79, on p. 252.

${ }^{25}$ Van Heyningen database of Cape licensed doctors; The Medical and Pharmacy Register for the Colony of the Cape of Good Hope, Cape Town, Richards, 1893; South African Medical Directory, Cape Town, Cape Times, 1896 and 1914.
}

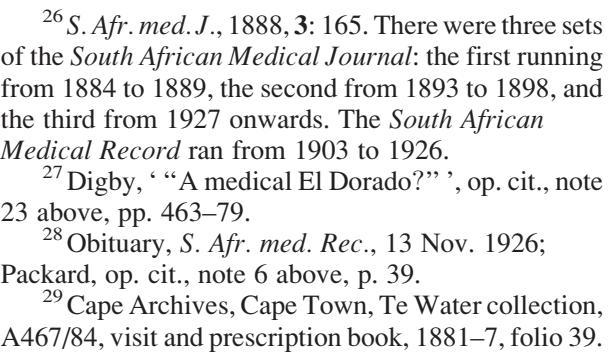




\section{The Career of Thomas N G Te Water (1857-1926)}

Water had been well trained: he was attentive to the patient's narrative and also examined the patient systematically. The doctor was not only a thorough clinician but also seems to have had a sympathetic bedside manner because he elicited the views of his patients including their perceptions of their maladies.

The next visit book indicates that by 1882 , his second year of practice, case records had already been attenuated to the more usual kind of clinical annotations kept by a busy GP. ${ }^{30}$ From this one might infer that the leisurely pace of initial practice had speeded up, and that the doctor's increased caseload, as well as an accompanying growth in professional experience and self-confidence, had made it seem superfluous to keep very detailed records. From a prescription book for 1888-94, it is evident that Te Water built up an extensive practice not only in the town but in the surrounding rural hinterland as well, although it is not possible to estimate the precise number of patients. ${ }^{31}$ The family nameas well as his skill as a doctor-may well have paid dividends in boosting patient recruitment. Te Water appears to have been a conscientious doctor who provided careful prescriptions attuned to the individual needs of patients. He visited acute cases frequently, but was prepared to supply repeat medication for patients with chronic complaints who lived some distance away. The large amount of analgesics prescribed suggests either that patients called out the doctor for painful illnesses that were unresponsive to prior selfmedication, and/or that a country patient distant from the doctor (and reluctant to incur another expensive visit) required the assistance or reassurance of having painkillers at hand.

Minor surgery was conspicuous, as indeed was also the case in contemporary rural practices in Britain, so that the day book for 1899 showed gums lanced, ears syringed, and fingers bandaged or dressed after surgery. Pessaries were inserted, injections given, and ringworm painted with iodine. On a more serious level, broken bones were set with splints, pieces of foreign matter extracted, uvula removed and, in a painful procedure (presumably for venereal disease), nitric acid used to cauterize a patient's penis. ${ }^{32}$ Travelling representatives of pharmaceutical firms helped keep the practice up-to-date so that modern products were made available, as in the use in 1899 of Burroughs Wellcome tabloids for the thyroid problem of a patient. ${ }^{33}$

The practice handled only a very small number of accouchements, as was shown by a case book for 1894-7. This was usual in Cape medical practice, where doctors attended only about one out of four confinements because most mothers continued to employ uncertificated women, particularly "coloured" (i.e. mixed race) midwives. ${ }^{34}$ This practice continued despite the fact that the Cape Colony was the first in the world to register qualified midwives in 1891. A contributory reason for the employment of local midwives may have been the frequent inability of a busy doctor to guarantee his presence at childbirth because he would be making calls over a wide area. Indeed, the term "BBA" or "born before arrival" was also found in British general practices, where the distances the doctor

The prescription books in the practice are effectively case books rather than prescription books.

${ }^{30} \mathrm{~A} 467 / 84$, visit book, 1881-7.

${ }^{31}$ A467/85/1, prescription book, 1888-94.

${ }^{32}$ A467/85/2, day book, 1899.

\footnotetext{
${ }^{33}$ A467/62, letter from S Cox of Mawson and Thomson of London, 4 July 1895; A467/85/2, day book entry, 11 Apr. 1899.

${ }^{34}$ Cape government papers, A6-1890, Report of the Select Committee on the Medical Practitioners Bill, Q.
} 
had to travel were usually much less than in South Africa. ${ }^{35}$ So it is no surprise to find the following entry by Te Water's (unnamed) locum. "I had just gone out on my rounds when they sent for me. I did not get there until 11.30 when I found that the child had been born naturally.",36

The rural South African patient frequently lived a long distance from formal medical assistance, and many relied on self-medication for less serious ailments. But more troubling or serious afflictions made some patients in the countryside come to stay in GraaffReinet for the period it took the doctor to treat them. Alternatively, patients within travelling range might seek a visit from the doctor. As in Britain and the USA, doctors benefited from improvements in communications during the late nineteenth and early twentieth century. This enabled practitioners to make a more economical and effective use of all their resources including their time, to develop larger practice areas, as well as achieve more expeditious patient-doctor contact. Before this period the rural Cape doctor was alleged to have been "very much more of a rough rider and expert cart driver than a prescribing physician". 37 Although more historical attention has been given to the later impact of the phone and the car on medical practice, ${ }^{38}$ Te Water's practice shows clearly the earlier impact made by railway and telegraph. Between 1873 and 1884 the railway was extended from Port Elizabeth to De Aar and took in Graaff-Reinet along the way. This was a considerable boon in cutting travelling times, as was the contemporary advance of the telegraph network, in that each shrank distance and extended the hinterland of a medical practice. The two working in combination can be seen in the following urgent summons of 1883 to Te Water to attend patients 30 kilometres away: "Come to Kendrew by tonight's train. Three children very ill. One in dying state." ${ }^{39}$ Dr Te Water's locum tenens recorded what a non-railway visit still meant for a doctor's workload in a visit of 1899. "17 June. Visited farm at Petersburg-left 3 pm returned 12 noon Sunday $18^{\text {th }} . " 40$ This trip was about twenty miles as the crow flew, but double that distance by road. In addition, the Midland Hospital in Graaff-Reinet gave sufferers another therapeutic option. Long-delayed because of an economic depression in the woollen industry during the $1860 \mathrm{~s}$, fund raising began in 1875 , and the small, four-ward hospital opened in 1879. It was designed for patients from "any class who, on account of distance from the town, find it impossible to secure medical attendance as their cases require". ${ }^{41}$

A number of out-of-town patients wrote to Te Water describing their symptoms in the kind of revealing detail that eighteenth-century British sufferers had done for distant consultants. ${ }^{42}$ In each case scarce medical resources were being stretched thinly across a wide geographical area. Characteristic of both sets of correspondence was a combination

\footnotetext{
355, evidence of Dr Herman of Cape Town; A467/85/2, prescription book, 1894-7; Cape Medical Museum, BMA Grahamstown Division minutes 1906-7, letter of 13 Jan. 1908 from Colonial Secretary.

${ }^{35}$ A Digby, The evolution of British general practice, 1850-1948, Oxford University Press, 1999, p. 205.

${ }^{36}$ A467/85/2, day book entry, 25 Aug. 1899.

${ }^{37}$ Editorial in S. Afr. med. Rec., Nov. 1904, 2.

${ }^{38} \mathrm{P}$ Starr, The social transformation of American medicine, New York, Basic Books, 1982, pp. 69-71;
}

\footnotetext{
Digby, General practice, op. cit., note 35 above, pp. 144-51.

${ }^{39} \mathrm{~A} 467 / 62$, telegram 28 Sept. 1883.

${ }^{40}$ A467/85/2, day book entry, 1899.

${ }^{41}$ A de V Minnaar, Graaff-Reinet, 1786-1996, Pretoria, Human Sciences Research Council, 1987, p. 29; A467/52, Fourth report of Midland Hospital, 1880.

${ }^{42}$ A Digby, Making a medical living, Cambridge University Press, 1994, ch. 6.
} 


\section{The Career of Thomas N G Te Water (1857-1926)}

of the sufferer's power of self-description with an overall psychological dependence on the doctor's clinical judgement. A Graaff-Reinet patient wrote:

I am going out to the country tomorrow. I am up today 6 days. I feel better today than any day but my tongue is still white. I can't get it clear. My legs is [sic] also a little weak so I thought a change would do me good. My appetite is very good. Just send me something or let me know what to do. ${ }^{43}$

With varying degrees of urgency patients asked the doctor to send medication: "I think a little strengthening medicine will do me good"; "send me some medicine as soon as possible", or even send medicine "by very fast train". ${ }^{44}$ The doctor seems to have preferred to send medicines through the postal service rather than by means of the railway or by Cape cart as was suggested by his patients.

The tone of these patients' letters varied-presumably being influenced by the relative social status of practitioner and sufferer, as well as by the degree of formality thought appropriate. There is an interesting contrast between the following letters; the respectful manner of the first, the polite unhappiness of the second, and the imperious character of the third:

Doctor, With patience and confidence I used your medicine to the last drop, and I think I can safely say I feel a bit relieved, should you think it advisable, you can send me some more.

Dear Sir, Nearly all the medicine has been used by me, also the starchy water. I am sorry to say I find no relief whatever ... Trusting you may give me some other medicine that will help. I remain dear sir yours obediently.

My dear doctor, I have finished the medicine, cannot say it has done me much good, seemed to upset my appetite; my hearing is better some times; left ear is discharging again and seems to prevent me from hearing; ought I not to syringe in such a case[?] Yours truly. ${ }^{45}$

Accompanying these letters on the clinical state of the patient were a few concerned with more mundane matters. Some reflected the fairly crowded state of the medical market in Graaff-Reinet. Patients might exploit this kind of situation to their own advantage by playing off one practitioner against another. For example, before turning to Te Water, one chronic sufferer had already received the ministrations of Drs Meintjes and Bishop. ${ }^{46}$ Another patient was dissatisfied with the tardy arrival of his medical attendant and so sought help from Te Water, writing haughtily, "I'll tell Dr Cooper when he calls tomorrow that I have decided to take another doctor". ${ }^{47}$ And, when Dr Cheeseman was himself ill, his patient summoned Dr Te Water for some medication that he considered was an urgent necessity. $^{48}$

This kind of ephemeral loyalty by patient towards doctor was so conspicuous that medical journals published many complaints by practitioners about the propensity of patients to change their doctor and thus escape paying medical bills. A letter to the

\footnotetext{
${ }^{43}$ A467/62, letter of 10 Dec. 1881 from P M Q.

${ }^{44}$ A467/62, letters of 1 May, 19 Sept. and 23 Feb. 1882 from A S; H P; and E H R E.

${ }^{45}$ A 467/62, letters of 13 Sept. and 19 July 1882 from C J S and J A H, and of 1 Mar. 1895 from T C S
}

\footnotetext{
${ }^{46} \mathrm{~A} 467 / 62$, letter of $23 \mathrm{Feb}$. from E E.

${ }^{47}$ A 467/62, letter of 15 July 1888 from D J L.

${ }^{48}$ A 462/62, letter of 8 Dec. 1889 from C F G R.
} 


\section{Anne Digby}

South African Medical Journal in 1886 even argued that "the nearer the doctor's financial arrangements approximate to the cash system, the better" ${ }^{49}$ This was remarkably different from professional sentiment in Britain where the "sixpenny" or "shilling" doctor who demanded cash before treatment was a potent symbol in signifying loss of professional standards and respectability. ${ }^{50}$ In contrast, in South Africa the non-paying patient became such a source of medical irritation that some doctors even advocated that a blacklist of non-paying patients should be kept by all the practitioners in a locality. ${ }^{51}$ Indeed, the vulnerability of medical incomes to agrarian economic fluctuations meant an open professional acknowledgment that South African medicine was a business-much as was the case in the USA-in contrast to Britain where a gentlemanly ethic inhibited much public discussion of the subject. ${ }^{52}$

Like others in the Cape, the Te Water practice was run as a small business. The doctor's standard visiting fee of three shillings was adjusted according to the distance he had to travel to a patient, as was customary in a situation where doctors found much of their time was occupied in long journeys. But economics was tempered by humanity such that a degree of medical altruism was apparent. Impoverished widows, for instance, might be charged a discounted fee of one shilling for the doctor's services, with medication also included, whereas Te Water usually charged for medicine separately from the fee for visits. ${ }^{53}$ An accountant was employed by the practice to make sure that notional income was translated into real assets. For example, in 1889 a guarantor was requested to ensure that payment for treatment was received from a hotel visitor, before any professional help was given. ${ }^{54}$ Only trusted residents were allowed to accumulate large bills. ${ }^{55}$ When patients were unable to pay the doctor's bill they had to explain their circumstances: "I am in receipt of your account which I am sorry to say I can't settle at once, as I am at present out of money but at all events I will send the amount before the $20^{\text {th }}$ of next month." 56

Calibrating billing for medicines in the practice was dependent on the amount supplied in varying sizes of bottle as well as the cost of ingredients. Like most largely rural practices, Te Water's was a dispensing practice, and he was formally licensed to practise as an apothecary as well as a doctor by the Cape Medical Council. Te Water obtained his drugs from a wholesale druggist in the town, Tebb and Co., as well from Heynes Mathew of Cape Town. ${ }^{57}$

In Britain, public salaried appointments provided the "jam on the bread and butter" of general practice remuneration, but in the Cape such offices were much fewer and therefore the object of fierce competition. In Graaff-Reinet one of Te Water's colleagues, Dr Welchman, secured the post of railway medical officer. Perhaps this was not too much

\footnotetext{
${ }^{49}$ Letter from Dr W C Scholtz of Cape Town to S. Afr. med. J., 1894-5, 2-3: 307-8.

${ }^{50}$ Digby, Medical living, op. cit., note 42 above, pp. 51, 168-9.

${ }^{51}$ S. Afr. med. Rec., 1887, 4: 69; S. Afr. med.J., 1897-8, p. 38.

${ }^{52}$ Digby, Medical living, op. cit., note 42 above, $\mathrm{p}$. 125; Digby, " "A medical El Dorado?", , op. cit., note 23 above, p. 477.
}

\footnotetext{
${ }^{53}$ A467/85/1, prescription book, 1888-94, folio 157b, Widow R.

${ }^{54}$ A467/91/1, slip signed by F de Klerk for payment for man and child at the Maudsley Hotel.

${ }_{55}$ A 467/89, receipts.

${ }^{56}$ A 467/62, letter of 20 March 1883 from J T S.

${ }^{57} \mathrm{~A} 467 / 89$, receipts and licences.
} 


\section{The Career of Thomas N G Te Water (1857-1926)}

of a disappointment because such positions meant absence for long hours up and down the line, and hence the loss of private medical income. Only in 1888 on the death of the incumbent, the elderly Dr Arenhold, did Te Water achieve the other main salaried postthe comparatively attractive appointment of district surgeon. In addition, Te Water had a contract to provide medical services for the Cape Police, which brought in small sums, and also received $£ 50$ per annum from the government to treat patients under the Contagious Diseases Act of 1885. Fees from private patients thus provided almost all of the practice's revenue, instead of the two-thirds usual in a well-established British general practice, where a sizeable, steady income from salaried appointments gave financial stability to many doctors. ${ }^{58}$ Te Water was fortunate to have a number of wealthy farmers and business people as patients so that fee income was sufficiently buoyant by 1899 for the practice to be making around $£ 2,500$ gross per year. This exceptional income would have placed the practice amongst the most financially successful of Cape medical practices because later official figures showed only about one in ten doctors earned more than $£ 1,000$ a year gross. ${ }^{59}$ This medical income was then used to sustain Te Water's later political career.

Graaff-Reinet was a growing town: a population of 14,687 in 1865 had increased to 19,256 by 1911 . Of these rather under two-fifths were white. The remaining population were Khoi or "coloured" people (whose numbers were equivalent to whites), and Africans (Xhosa, Mfengu and Tembu) whose numbers had risen from one in six to one in four during these years. ${ }^{60}$ In Te Water's financial records non-white patients were almost invisible and this seems likely to have been due less to their receiving attention Pro Deo (where free service would have gone unrecorded in the accounts) than that impoverished "coloured" and African sufferers would not even have approached him. ${ }^{61}$ As with other "western" practitioners, it was a black servant in a white family who had some chance of receiving private medical attention. For example, a bill was sent out for attending "Mr H Vorster's 'kafir boy', [at] Fonteinplaats". ${ }^{62}$ The bill went to the white employer and the African adult patient (the "kafir boy") was treated with "western" medicine. Te Water practised the biomedicine inculcated by his training, showing no interest in indigenous medicine, and in this narrowly-focused gaze Te Water was typical of most western-trained doctors of his generation. ${ }^{63}$ Only a few contemporary general practitioners such as the English-born Dr Henry Taylor or the Afrikaner, Dr J B Knobel, exhibited an interest in African medical remedies (albeit from critical standpoints), and thus showed awareness of the pluralistic possibilities for medicine in South Africa. ${ }^{64}$

\footnotetext{
${ }^{58}$ A467/91/1, papers relating to office as district surgeon; A467/89, receipts; Digby, Medical living, op. cit., note 42 above, ch. 5 .

${ }^{59}$ A467/85/2, receipts, Apr.-Sept. 1899; Cape government papers, G49-1909 Cape of Good Hope report of Commissioner of Taxes, 1908-9. For a discussion of the Cape doctor's finances see Digby, “ "A medical El Dorado?", op. cit., note 23 above, pp. 478-9, and idem, 'Making a medical living', op. cit., note 24 above, pp. 249-80.

${ }^{60} \mathrm{~S}$ Dubow, Land, labour and merchant capital in the pre-industrial rural economy of the Cape, University of Cape Town, Centre for African Studies, 1982, p. 3; Minnaar, op. cit., note 41 above, p. 151.
}

\footnotetext{
${ }^{61}$ UG 54-1937, Report on Cape coloured population, paragraphs 508, 512, 523-4.

${ }^{62} \mathrm{~A} 467 / 62$, bill dated Jan. 1890.

${ }^{63}$ Digby, Diversity and division in medicine, op. cit., note 12 above, pp. 345-63, 371-2.

${ }^{64}$ Hadley (ed.), op. cit., note 7 above, pp. 34-5; J B Knobel, 'Some remarks on the professional experiences of a general medical practitioner in Pretoria, Transvaal', MD thesis, University of Glasgow, 1902, p. 24. Taylor practised mainly in Ficksburg in the Orange Free State, and Knobel mainly in Pretoria in the Transvaal.
} 
Some problems for his continuing medical practice were posed by Te Water's later career as a provincial politician. Towns such as Graaff-Reinet found it difficult to recruit able individuals to represent them in the Cape Parliament, because of prolonged absences from their profession or business in Cape Town, 400 miles away. ${ }^{65}$ In Te Water's case his absence led first to a temporary assistant, and later to a more permanent locum tenens being used. Letters in 1894 from the inexperienced young assistant to his principal give an interesting insight into the practice. The assistant visited ten patients or more a day as well as attending to others in the surgery, and learned to use the cheapest medicines, rather than prescribing medicine regardless of price, as he had used to do during his earlier hospital training. He found it necessary to get on with other doctors, despite his initial assumption that "I do not think it is possible for two medical men in a small place whose interests are not identical to love each other very much". ${ }^{66}$ And he later discovered that a colleague, Dr Hudson, was prepared to help him in a surgical operation on a patient's knee, while in turn he looked after Hudson's cases when the latter was away on a vaccination tour. ${ }^{67}$ But by 1898 Te Water's problems in running a practice from a distance had precipitated more serious local concern. After five years of his frequent absences in Cape Town, the Managing Committee at the Midland Hospital where Te Water held an unpaid appointment, wrote that the "long-continued acting" of his locum tenens meant that this "virtually assumes the character of an appointment without the Board having a voice in the matter", and asked Te Water to help them out. Te Water acted honourably and his resignation was accepted. ${ }^{68}$

\section{Public Health and Political Activity}

In contrast to his work as a private practitioner which focused almost exclusively on white patients, as district surgeon Te Water had also to concern himself with those from other parts of the community not least because their diseases might impact on white health. Here he was responsible for the medical care of prisoners, paupers and other classes of person targeted by legislation, such as cases of STI or of leprosy. The death rates for racial groups in the Graaff-Reinet district indicated stark differentials: 20.2 for whites but 45.5 for those designated "coloureds" ${ }^{69}$ His public duties therefore brought the doctor into contact with a much less healthy portion of the population although this did not appear to alter his restricted political consciousness of the nature of community. Interventions were directed mainly or exclusively at non-whites, then largely excluded from the Cape franchise, and within this context of public health Te Water seemed unaware of tensions between the ideological goals of community benefit and of individual liberty. An awareness of these issues as they affected the white community surfaced later in his ministerial speeches on the Public Health Amendment Act of 1897 where he sought to allay the anxieties of whites about potential interference with their property on sanitary grounds. ${ }^{70}$

\footnotetext{
${ }^{65}$ Minnaar, op. cit., note 41 above, p. 45.

${ }^{66}$ A467/62, letter to Te Water, 6 July 1894.

${ }^{67} \mathrm{C}$ H Hudson, CM, MD, Edinburgh.

${ }^{68}$ A467/62, letters, 9 Dec. 1898, 8 Apr. 1899.

${ }^{69} \mathrm{~A} 467 / 94$, minutes and correspondence, figures for 1896 .
}
${ }^{70} \mathrm{D}$ Porter, Health, civilisation and the state: $a$ history of public heath from ancient to modern times, London, Routledge, 1999, p. 146.




\section{The Career of Thomas N G Te Water (1857-1926)}

Te Water took his duties as district surgeon seriously, adopting an interventionist stance, as did most contemporary medical colleagues. He was keen to improve local public health, if necessary by expanding public facilities, as in 1889 when he advocated setting up a lying-in hospital. ${ }^{71}$ Like his colleagues he was frustrated at what he perceived to be local apathy, ignorance and indifference towards the controversial Contagious Diseases Prevention Act of 1885. The first such act had been passed in 1868 but had been repealed four years later, because of influential opposition to its threat to individual liberty, while attempts to control contagious diseases under the Public Health Act of 1882 had been unsuccessful. The Contagious Diseases Act was thus contentious (as had been the case in Britain and India) and in South Africa involved several select committees on the question. $^{72}$ The 1885 act had made it compulsory for "coloured" and African sufferers from syphilis to be treated by the district surgeon, and incarcerated in segregated gaols or lock hospitals in order to protect the white population. Elizabeth van Heyningen has commented aptly that through these pieces of legislation the Cape medical profession "was beginning to assume the role of arbiter of the Colony's morals". ${ }^{73}$

Te Water termed syphilis a loathsome condition, thought it was "undermining the health of the community", and regretted that it was only when cases reached an advanced stage that individuals got treatment at the Contagious Diseases Hospital in the town. He was concerned about the case of an infected butter-seller in the town's morning market, as well as that of a diseased washerwoman, pointing out that in each instance their work could transmit the disease to others. "Only in the hearty cooperation of all in the application of the provisions of the act is there a possibility of stamping out the disease", he concluded and argued passionately that all public servants should pay special attention to infected cases. ${ }^{74}$ In his first report as district surgeon he wrote thoughtfully, systematically and at greater length on this issue than his Cape colleagues, drawing his information from farmto-farm visits. "The conclusions I have come to from data thus collected and from private observation for some years are that syphilis prevails more extensively in the district than was ever suspected". ${ }^{75}$ At this time Te Water wanted strict enforcement of the act, with more thorough inspection and with suspicious cases of syphilis compelled to be examined and treated. ${ }^{76}$ Informing this was the white population's fear of racial contamination through disease.

The doctor showed forceful determination in tackling issues in public health, although along racially differentiated lines. In leprosy, where only non-white cases might be compulsorily removed or isolated, Te Water considered that any measures "should be drastic. Half measures are too dangerous, giving a false sense of security" ${ }^{77}$ In this his view was in line with other medico-politicians. For example, Dr J W Matthews took the opportunity whilst serving from 1881 to 1883 as the senior member for Kimberley in the Cape House of

\footnotetext{
${ }^{71}$ A467/91/1, newspaper cuttings.

${ }^{72} \mathrm{P}$ W Laidler and M Gelfand, South Africa: its medical history, 1652-1898, Cape Town, Struik, 1971, pp. 454-60.

${ }^{73} \mathrm{E}$ van Heyningen, 'The social evil in the Cape Colony, 1868-1902: prostitution and the Contagious Diseases Acts', J. Southern Afr. Stud., 1984, 10 (2): 170-97, pp. 174-5, 178.
}

\footnotetext{
${ }^{74}$ A467, correspondence, 1897-1905.

${ }^{75}$ Cape official papers, G4-1889, Reports of district surgeons on Public Health, pp. 47-9.

${ }^{76}$ G5-1891, ibid., 1890, p. 36.

${ }^{77}$ G5-1891, ibid., p. 36; A467, correspondence, 1897-1905 for draft statement on leprosy.
} 
Assembly to visit the "coloured" lepers compulsorily segregated on Robben Island (together with a few whites who had volunteered for treatment), when he expressed the conviction that only "complete segregation could ever stamp out this dreadful disease". ${ }^{78}$ Such interventionist measures in public health had, as van Heyningen comments, "given the medical profession unjustified confidence in its ability to control disease". 79

Te Water's move into political activity was a logical career progression. He was encouraged to go into politics by his life-long friend, J H Hofmeyr, who continued to act as his political mentor. Hofmeyr was the uncrowned leader of the Afrikaner Bond which, by the 1890s, was the most powerful political group in the House of Assembly. ${ }^{80}$ In existence from 1880 to 1919, the Bond proceeded pragmatically and exhibited ideological fluidity in reflecting and upholding Afrikaner farming interests. It often lacked cohesion so that leaders and local supporters might find themselves divided over contemporary issues. The Bond was also racist and had been instrumental in disqualifying about a quarter of the Cape's black voters through the Voters Registration Act of $1887 .{ }^{81}$ For the 1893 election the Bond sought capable professional men to represent it in the House of Assembly. ${ }^{82} \mathrm{Te}$ Water clearly fitted this description, as well as having the benefit of a strong basis of electoral support because he had held the chairmanship of the Afrikaner Bond in GraaffReinet since 1887. In addition, it seems likely that Te Water was imbued with the strong tradition of public service of his family: his maternal grandfather, T N G Muller, had been a member of the first Cape Assembly in 1854 and his father, F K Te Water had been elected to serve in the Cape Legislative Council from 1869 to $1877 .{ }^{83}$ In his turn, Thomas N G Te Water was elected in 1893 to the Cape Legislative House of Assembly to represent the Bond.

National politics was complex and volatile during the 1890s when Te Water entered political life. From 1890 Cecil Rhodes was premier of the Cape with a ministry sustained by an apparently unlikely alliance dating from 1889 between his own imperialist mining interests and the Afrikaner Bond's local, agricultural ones. This alliance was underpinned by a shared belief in the hegemony of white colonial interests and sustained by personal rapport between Hofmeyr and Rhodes, as well as by the accommodating pragmatism of Bondsmen who pursued politics as the art of the possible. ${ }^{84}$ After his election in $1893 \mathrm{Te}$ Water acted as a whip for the alliance in the House of Assembly. But both Rhodes' premiership and the formal alliance with the Bond were ended by the abortive Jameson Raid of December 1895. Led by Rhodes' close friend, Dr Leander Starr Jameson, and

\footnotetext{
${ }^{78} \mathrm{~J}$ W Matthews, Incwadi Yami; or twenty years personal experience in South Africa, Johannesburg, Africana Book Society, 1976, pp. 343, 351.

${ }^{79}$ Van Heyningen, 'The social evil', op. cit., note 73 above, p. 195.

${ }^{80}$ J H Hofmeyr or "Onze Jan" (1845-1909) represented Stellenbosch in the House of Assembly (1879-1895) but, on the grounds of poor health, held cabinet rank only for a brief interval in 1881 . However, he had immense influence as the acknowledged leader of the Bond, where he displayed great tactical skill in complex political manoeuvres (DSAB, 1972, vol. 2, pp. 314-19). Hofmeyr continued to be Te Water's political
}

mentor as when Te Water sought his friend's advice before accepting ministerial office in Sprigg's ministry in 1896.

${ }^{81} \mathrm{M}$ Tamarkin, Cecil Rhodes and the Cape Afrikaners: the imperial colossus and the colonial parish pump, London, Frank Cass, 1996, pp. 135-7; A Thomas, Rhodes, London, BBC Books, 1996, pp. $167-8$.

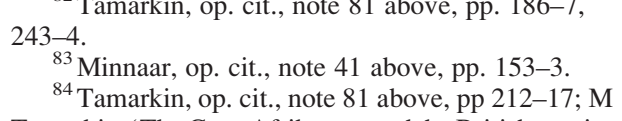
243-4.

${ }^{83}$ Minnaar, op. cit., note 41 above, pp. 153-3.

${ }^{84}$ Tamarkin, op. cit., note 81 above, pp 212-17; M Tamarkin, 'The Cape Afrikaners and the British empire 


\section{The Career of Thomas N G Te Water (1857-1926)}

acting in collusion with the British government, the expedition had aimed to overthrow the South African Republic's government, and so control the rapidly expanding wealth being generated by the Witwatersrand gold mines around Johannesburg in the Transvaal. The Raid politicized the Bond as well as increasing the polarizing tendencies in white South African society. The two Afrikaner republics of the South African Republic and the Orange Free State drew more closely together, and in subsequent years were increasingly concerned to preserve their independence from Britain's aim of consolidating its supremacy in South Africa within an international scramble for Africa. After declarations of war from the two republics, the South African War began in October 1899. It was both a critical chapter in the history of South Africa and an episode in British imperial history. ${ }^{85}$ After a devastating conflict, it ended in May 1902 with the British having successfully completed their imperial conquest of South Africa. ${ }^{86}$

As a local politician, Te Water had aimed to defuse the ethnic tensions in the white community that had become so evident in municipal and divisional elections before his election in 1893. The inhabitants of Graaff-Reinet and its surrounding district were conspicuously split between Dutch (later termed Afrikaner or Boer) agriculturists and wealthier English business people. ${ }^{87}$ A political asset was that although Te Water's home language was English, and his wife, Minnie (née Currie), came from a leading town family of British settler stock, his political sympathies were Afrikaner. (Professionally, this broad appeal also helped the doctor's medical practice as his practice records show that he was able to recruit comparable numbers of Afrikaner and English patients.) In political affairs Te Water promoted the term "Africander" to embrace "people of all nationalities whether French, English, Dutch, German”. He refuted opponents' allegations that the Bond was disloyal to the British Crown by arguing eloquently that "we desire to secure to the Africander population the rights to which we as British subjects are entitled" 88 Te Water was aware of the need to bridge the different white ethnic sensitivities in his constituency and, when elected to the House of Assembly, he chose English for his victory speech, although its content highlighted Afrikaner interests. ${ }^{89}$

The Cape had had a particularly close relationship between doctors and the state stemming from the regulation and licensing of the medical profession from as early as 1807. Other medical practitioners had found that a well-established medical practice, with the high public profile that this entailed, might assist in constructing the basis of a political constituency. For example, in the first Cape Legislative Assembly of 1853 Dr F L C Biccard (of Durbanville and Malmesbury), Dr Abercrombie, Senior (of Cape Town), and Dr H White (of Swellendam) had been elected members; all later serving in the Upper House. In 1856 these three served on the Select Committee on the Practice and Sale of Medicines, which discussed the competition that unlicensed quacks, storekeepers and traders posed to licensed doctors in remote or frontier areas. Three doctors-White,

from the Jameson raid to the South African War', in D Lowry (ed.), The South African War reappraised, Manchester University Press, 2000, pp. 121-39, on p. 128; Thomas, op. cit., note 81 above, pp. 265-72.

${ }^{85}$ Tamarkin, op. cit., note 84 above, p. 127.

${ }^{86} \mathrm{R}$ Davenport and C Saunders, South Africa: $a$ modern history, 5th ed., Basingstoke, Macmillan, 2000, p. 230; B Nasson, The South African War, 1899-1902, London, Arnold, 1999, p. xi.

${ }^{87}$ Minnaar, op. cit., note 81, pp. 14, 39.

${ }^{88} \mathrm{~A} 467 / 91 / 1$, speech following the Bond victory in the Graaff-Reinet divisional elections of Nov. 1888.

${ }^{89}$ A467/88, newspaper cuttings, 1888-96. 
Te Water as well as Sir Thomas Smartt-went on to hold ministerial office, while Sir William Bisset Berry and Te Water became Speakers in the House of Assembly. ${ }^{90}$ Whilst some medico-politicians like White and Dr Christie (of Beaufort West) became full-time politicians, Te Water, together with Matthews and Dr W G Atherstone (of Grahamstown), managed to combine medical practice with political activity.

The notable polymath, W G Atherstone, was a member of the Cape Assembly from 1881 to 1883 , and of the Legislative Council from 1887 to 1890 . Like Te Water he made a considerable professional input in public life. Atherstone gave evidence to the Select Committee on Leprosy that led to reforming legislation in 1884; promoted his views on the importance of compulsory notification of contagious diseases before improved legislation on the subject was passed in 1885; visited British mental asylums in 1887 with a view to learning from best practice how to improve the condition of the Cape insane; wrote an early draft of the Medical and Pharmacy Act of 1891; and helped stimulate the foundation of a Colonial Bacteriological Institute in Grahamstown that dealt more with veterinary than medical questions. ${ }^{91}$

Like Atherstone, Te Water represented Eastern Cape interests, gaining valuable local endorsement for his political ambitions in supporting non-medical issues important to his rural constituents. He backed the strategic extension of the railway to the town, gave charitable support to "poor whites" in the rural Afrikaner community, and was active in a multiplicity of local organizations. ${ }^{92} \mathrm{He}$ also promoted veterinary matters such as the efficient administration of the Scab Act of 1886 that aimed to improve animal health in this important sheep rearing area of the Karoo, where the spread of scab disease could drastically lower the value of the wool on which the economy of the area depended, and his private papers included manuscript returns from the local scab inspector. ${ }^{93}$ However, Te Water's belief in intervention was not shared by all his constituents. In Midland constituencies such as Graaff-Reinet an anti-scab movement of sheep farmers believed that a scab inspector's interventions would be oppressive to a free people as well as causing crippling expenditure to small farmers. Their pressure succeeded in blunting some of the more forceful clauses of the bill. ${ }^{94}$

Te Water achieved Cape ministerial office in two short-lived ministries, first as Colonial Secretary in Sir Gordon Sprigg's cabinet from July 1896 to May 1898, and then as Minister without Portfolio in W P Schreiner's ministry from 1898 to $1900 .{ }^{95}$ Both had a broad portfolio enabling him to pursue medical interests, although being constrained by holding office within the problematic context of the hardening of racial political positions before and during the South African War. As we have seen, Te Water was a member of the Afrikaner Bond, which after 1896 opposed the pro-British Progressives linked to Cecil

\footnotetext{
${ }^{90}$ Burrows, op. cit., note 22 above, pp. 110, 129, 154-5; van Heyningen, 'Public Health', op. cit., note 6 above, pp. 98-9.

${ }^{91}$ Mathie, op cit., note 7 above, vol. 2, pp. 437-9, vol. 3, 817-19; Burrows, op. cit., note 22 above, p. 173.

${ }^{92} \mathrm{~K}$ Wyndham Smith, From frontier to Midlands. a history of the Graaff-Reinet district, 1786-1910, Occasional Paper 20, Grahamstown, ISER, Rhodes University, 1976, pp. 85, 91, 100, 337-41.
}

\footnotetext{
${ }^{93}$ G1-1894, Report of the Scab Disease Commission, 1892-4, inter alia, evidence of F L McCabe, scab inspector for the Graaff-Reinet district, pp. 147-79.

${ }^{94}$ Tamarkin, op. cit., note 81 above, pp. 206-10.

${ }^{95}$ E A Walker, W. P. Schreiner, Oxford University Press, 1937, p. 116; DSAB, vol. 5, pp. 766-7.
} 
Rhodes. Te Water's resignation from Sprigg's ministry was occasioned by a bill to redistribute seats in the House of Assembly that Te Water considered would have provided the Progressives with a majority, and hence would have given a decisive influence to free trade townsmen against the Bond's protectionist stance in defence of agrarian interests. ${ }^{96} \mathrm{Te}$ Water stated that "the influence of the country party would be destroyed ... The object of the Bill was solely to support the diamond-mining industry and the interests of the cities, and to neglect the farmer's interests". ${ }^{97}$ Schreiner's succeeding ministry was unusually dependent on the support of the Bond but, as a Bond member, Te Water marginalized himself. He was perceived as lacking in vision within an increasingly polarized situation, and was criticized by Schreiner for strong protests but poor attendance. Te Water believed that Schreiner was not making enough of the Cape Colony as a third party in the looming conflict between the Boer Republics and Britain. Ultimately, the opinions of his ministers became so irreconcilable that in June 1900 Schreiner resigned. ${ }^{98}$

That these ministries managed to achieve anything was remarkable when, as Davenport comments, "the dice were loaded heavily against" them. ${ }^{99}$ As a minister, Te Water promoted public health and veterinary issues. He took great pains to get the Public Health Amendment Act of 1897 on the statute book, after it had languished on the sidelines following a first legislative draft five years before. Here he highlighted the threat that disease posed to the health of the community, referred to the shocking state of health of the "coloured" population, as well as to insanitary conditions and the high death rates in the towns. Mindful of the wholly white representation in the Cape Assembly he was careful to emphasize that the community could not be dragooned into cleanliness; a contrast to his previous support as district surgeon for compulsory powers where non-whites were concerned. The 1897 legislation was important in centralizing and consolidating the powers of the $\mathrm{MOH}$, constituting the Colonial Medical Council as an advisory board of health, encouraging the appointment of local health officers, and extending their powers of enforcement over local sanitary matters together with those of district surgeons. ${ }^{100}$ Veterinary affairs were important given the value of agriculture to the economy, and Te Water paid close attention to the provision of serum for infected herds. The Scab Bill of 1898 made sheep dipping universally compulsory with a new Ministry of Agriculture formed to enforce more stringent regulations. ${ }^{101}$ In addition, Te Water represented the Cape at a South African conference in 1899 to discuss Asiatic plague, which drew up quarantine regulations for ships visiting from infected areas. ${ }^{102}$

Te Water was instrumental in 1897 in revising the lunacy law in a policy area having a racially differentiated impact. Under the lunacy codes of 1891 and 1897 the mentally ill

\footnotetext{
${ }^{96}$ Walker, op. cit., note 95 above, pp. 34, 105, $109-10$.

${ }^{97}$ Quoted in Tamarkin, op. cit., note 81 above pp. 283-4.

${ }^{98}$ T R H Davenport, The Afrikaner Bond: the history of a South African political party, 1880-1911, Cape Town, Oxford University Press, 1966, pp. 21620; DSAB, vol. 5, pp. 766-7; Walker, op. cit., note 95 above, pp. 117-19, 225, 231-3; Davenport and Saunders, op. cit., note 86 above, p. 228.
}

\footnotetext{
${ }^{99}$ Davenport, op. cit., note 98 above, p. 248.

${ }^{100}$ A467/94, minutes and correspondence; Laidler and Gelfand, op. cit., note 72 above, p. 451.

${ }^{101}$ A467/95/2, telegram books of Colonial Secretary. Permissive legislation had first been enacted in 1886 and vigorous discussion had occurred ever since then over its suitability for different ecological areas.

${ }^{102}$ Laidler and Gelfand, op. cit., note 72 above, p. 490 .
} 
were perceived as a potential danger to colonial society's public order, and unlimited new powers were provided to commit those "wandering at large" in order to police public safety. In 1897 Te Water responded to the pleas of leading asylum doctors, W J Dodds and $\mathrm{T} \mathrm{D}$ Greenlees, by ensuring that streamlined procedures for emergency admission orders were enacted, whereby the distinction between ordinary and dangerous cases (specified in 1891) was removed. Felicity Swanson has argued persuasively that this legislation exemplified the unequal power relations of the Cape in privileging white interests over black because, within a society characterized by growing rates of labour migrancy, it led to soaring rates of commitment of black males. ${ }^{103}$ Te Water also took an interest in the newlyestablished Emjanyana Leper Asylum, where African patients suspected of having leprosy could be compulsorily detained under legislation of 1891, and where unrest was becoming apparent. $^{104}$

The consciousness of a Cape Afrikaner and Bondsman was highly complex involving an identity as a Cape colonist that coexisted with a loyalty to the Crown, and to the empire conceived as a free, loose association rather than the much tighter imperial conception of the British. ${ }^{105}$ This hybridity created difficulties for Te Water within the flux of Cape politics before and during the war. Te Water's Bond constituents had earlier regarded his membership of Sprigg's and Schreiner's cabinets with some distrust because they were perceived to be too close to the interests of British imperialism. But constituents' fears were allayed when, after his resignation from Sprigg's cabinet in 1900, Te Water openly supported the Afrikaner/Republican cause. He campaigned against an imposition of martial law and opposed the disfranchisement of active rebels. Indeed Te Water went into voluntary exile in Europe for a time because he feared arrest as a "rebel". ${ }^{106}$ During the war, Te Water's constituency of Graaff-Reinet had been designated as a cavalry depot and base camp from which British forces could engage with Boer commandos, but the loyalty of many of Te Water's constituents was revealed when, after the war had ended, a monument was erected in the town in honour of several executed Boers. ${ }^{107}$

The end of the war in May 1902 was followed a few months later by Te Water's retirement from political and public life occasioned by a stroke from which he never fully recovered. But a decade later he was persuaded to become a member of the TB Commission appointed in 1912 shortly after the Union of the Cape with the three other colonies. The commission's chairman was Dr A John Gregory (MOH for the Cape from 1901 to 1910), who from 1891 had been in the Health and Local Government Department of the Colonial Office working on health statistics, and who therefore would have been a colleague of Te Water when he was Colonial Secretary. ${ }^{108}$ Other members of the commission were the Hon R Jameson (the single lay member), Dr Charles Porter (Medical Officer of Health to Johannesburg Municipality), and Dr George Turner (who from 1900 to 1908 had been Chief Medical Officer to the Transvaal, as well as being a medical adviser to the

\footnotetext{
${ }^{103}$ F Swanson, " "Of unsound mind": a history of three Eastern Cape mental institutions, 1875-1910', MA thesis, University of Cape Town, 2001, pp. 112-30. Water.
}

\footnotetext{
${ }^{105}$ Tamarkin, op. cit., note 84 above, pp. 133-5.

${ }^{106}$ Davenport, op. cit., note 98 above, p. 234.

${ }^{107}$ B J Barker, A concise dictionary of the Boer War, Cape Town, Francolin, 1999, p. 63.

${ }^{108}$ Van Heyningen, 'The social evil', op. cit., note 73 above, p. 196.
} 


\section{The Career of Thomas N G Te Water (1857-1926)}

Witwatersrand Native Labour Association handling migrant mine workers recruited from outside South Africa). Although sharing a similar professional background to the medically-qualified commissioners including an initial medical training in Britain, Te Water stood somewhat apart in that, unlike them, he had been born and bred in the Cape, had worked in general practice, and had public health expertise in rural rather than mining issues.

The commissioners were remarkably hard working, visiting seventy-six areas and taking evidence from over 600 witnesses. Not every commissioner visited each place, although Te Water was unusually assiduous in his attendance, while his close questioning of witnesses contributed to a brisk pace in the inquiry. His vigorous style and firm opinions were evident and are revealed in the two following examples. Te Water's successor as district surgeon to Graaff-Reinet was Dr C H Hudson who gave evidence about his twenty-one years of service in the post. Te Water showed dissatisfaction with Hudson's failure to consult registration statistics for precise figures on mortality, relying instead on consultation with colleagues to gain only an impressionistic view. Equally, Te Water viewed with disapproval Hudson's failure to visit the town's location, which would have enabled him to gain a better understanding of sanitary issues through direct observation of living conditions, and hence acquire an appreciation of the effects of this environment on the health of its "coloured" inhabitants. ${ }^{109}$ Indeed, the contrast between Hudson's routine pursuits and Te Water's earlier energetic activities was striking. Fittingly, the final report of the commission quoted approvingly from Te Water's earlier observations as district surgeon. ${ }^{110}$

A second encounter a few weeks later also revealed Te Water's decided professional views. Mining areas were objects of prime scrutiny for the commission, and in Kimberley, the centre of the diamond mining industry, Te Water was unusually assertive. Here he clashed with Dr J E Mackenzie, one of Kimberley's nine mine medical officers, who held an appointment as Medical Officer to the Wesselton Mine Compound Hospital that cared for De Beer's sick workers. Te Water's earlier sectional focus on the health of whites, and his concern for the way in which black disease might impact on the white community, meant that he was out of sympathy with the universalistic beliefs and egalitarian considerations of Mackenzie. Contrary to the views of Te Water (and other members of the commission), the Wesselton Hospital had a policy of retaining TB sufferers in the compound, rather than sending the sick miners back to their reserves. ${ }^{111}$ Mackenzie asserted, "[W]hen you send them out of the compounds they are spreading the diseases in their homes-which is [sic] the nursery of the labour market-worse than in the compounds." 112 Mackenzie's view was before its time and would have gained support from later commentators who deprecated the spread of tuberculosis to rural areas by migrant miners. ${ }^{113}$ A clash of political philosophy between Te Water and Mackenzie

\footnotetext{
${ }^{109}$ A 467/73, typescript of answers to commission, questions 83,868-74 and 83,933-44.

${ }^{110}$ UG 34-1914 Report of the Tuberculosis Commission, p. 17.

${ }^{111}$ Diamond Field Advertiser, 17 May 1913. J E Mackenzie, CM, MD, Edinburgh. He was the son of
}

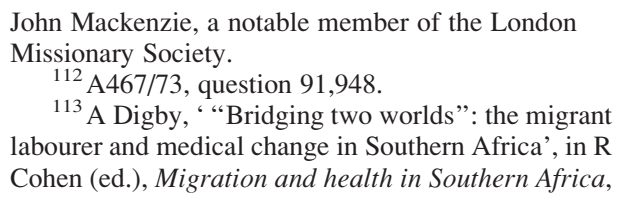




\section{Anne Digby}

was also evident when the latter expressed the kind of advanced liberal views befitting a son of a leading missionary family, in disagreeing with compulsion applied to an African but not a white miner, precisely because this would have involved what he regarded as undesirable racial differentiation. ${ }^{114}$ Mackenzie described the custom in the Wesselton Compound of allowing miners who had recovered from any active symptoms of tuberculosis to return to work; a practice strongly deprecated by the commission in its final report. ${ }^{115}$

Relationships within the commission showed growing tension. Porter and Turner used dissenting footnotes — based on an intimate knowledge of the mining industry-to challenge statistical conclusions in the commission's final report. ${ }^{116}$ Within the small professional world of public health, Gregory, Porter and Turner had had interlocking professional careers that it is possible had produced hidden resentments: Turner had worked with Gregory in the Cape, and Porter had been an unsuccessful applicant for a post to which Turner was appointed. ${ }^{117}$ Arguably a more substantive cause of disagreement was that Porter and Turner had had much more professional experience of health issues in the mining industry than had Gregory. Professional disagreement climaxed on the final evening when Gregory as chairman attempted to force his policy recommendations for the future control of mine workers and mine sanitation on his colleagues, but was rebuffed. In his minority report, Gregory challenged the professional integrity of Porter and Turner, by implying that they were identified with current systems of control and hence were insufficiently critical of a lack of oversight over mining.

During the commission's activities before this climacteric, Te Water had preferred to support the chairman's conclusions, but he found it impossible to back Gregory's final actions. The fact that he took six weeks before publicly supporting Porter and Turner by regretting Gregory's remarks perhaps suggests how difficult he found the situation. Te Water thought Gregory's allegations cast "grave reflections on the bona fides" of Porter and Turner, whereas Te Water asserted that "their thorough and accurate acquaintance" with the Witwatersrand (Johannesburg) gold mines had "proved of the greatest possible value" to the commission. "I wish most distinctly to dissociate myself from the suggestion against our two Johannesburg colleagues, which is unjust and without any foundation." "118 Professional disagreement rumbled on, with Gregory maintaining that it was in fact Porter and Turner who-by their sympathetic view of the needs of the mining industry - had succeeded in blunting the commission's conclusions. ${ }^{119}$ These professional differences of opinion had a longer-term significance in that Porter and Turner's belief-in a racial physiological paradigm in which Africans were

Cape Town, Struik, 2003, pp. 18-20; Packard, op. cit., note 6 above, pp. 92-102; F Wilson, Migrant labour in South Africa, Johannesburg, South African Council of Churches, 1972, p. 183.

${ }^{114}$ A 467/73, question 92,024.

${ }^{115}$ UG 34-1914, page 152, paragraph 273.

${ }^{116}$ UG 34-1914, chapter X, where each commissioner stated an individual view of TB's infectiousness.

\footnotetext{
${ }^{117}$ Laidler and Gelfand, op. cit., note 72 above, pp. 442-3, 453, 469.

${ }^{118}$ UG 34-1914, addendum, 3 June 1914; Packard, op. cit., note 6 above, p. 202.

${ }^{119}$ S. Afr. med. Rec., 12 Sept. 1924, quoted in

Packard, op. cit., note 6 above, p. 351, note 18 .
} 


\section{The Career of Thomas N G Te Water (1857-1926)}

susceptible to tuberculosis-weakened the impact of the commission's criticism of environmental conditions in the mines, and thus undercut the reforming case for improvement. $^{120}$

\section{Conclusion}

Dorothy Porter has concluded that in the history of public health the impacts of medical knowledge were differentiated and diffuse, with both cultural and political contexts being important in framing them. ${ }^{121}$ This study has exemplified some aspects of this complex layering process in using a South African lens to look at the dual identity of Thomas Te Water as doctor and politician and at the constraints of the historical context within which he worked. As with most biographies, there has been an attempt to create an ordered narrative and a coherent biography out of varied and incomplete sources and thus, as Roy Porter has suggested, to "take a life", and diagnose a character on the basis of limited evidence. ${ }^{122}$ From this "collaboration" between historian and subject it has been suggested that Te Water was a skilled private medical practitioner despite working within the constraints of a rural practice. He was representative of the Cape medical profession in focusing on white patients, although there was an interface between his private doctoring for an almost exclusively white clientele and his duties as district surgeon that brought him into contact with the black population. He was untypical but not unique in the Cape medical profession in being interested in both medical and veterinary issues, the latter forming one bridge into a political career since this was of prime interest to many of his constituents. ${ }^{123}$ As a Cape politician, I have argued that, despite being a minister at an unpropitious time for reform, he was successful in promoting the application of medical knowledge within the public sphere. In "retirement" he was a notably active commissioner on an influential South African public health enquiry into tuberculosis.

At the first congress of the overwhelmingly white Cape medical profession, held at Kimberley in 1892, the year before Te Water became a medical politician, he gave an opening address. Here he stated, "I hailed this meeting as of importance because it indicated an intention of stirring up greater esprit de corps ... and especially I hoped that at this meeting the foundations would be laid which would make co-operation for the general good possible, a thing unfortunately an unknown quantity with us." ${ }^{124}$ Inadvertently in this statement he also revealed something about the philosophy that informed his own varied career as doctor and medical politician, characterized as it was by political moderation, attempted reconciliation between white ethnic groups in Graaff-Reinet, and a concern to improve what he perceived to be the general good through public health

\footnotetext{
${ }^{120}$ Packard, op. cit., note 6 above, pp. 201-3. See also Katz, op. cit., note 6 above, p. 103 , note 26 on p. 223 , note 28 on p. 235 . For discussion of belief in racial disease paradigms by the medical profession see Jochelson, op. cit., note 6 above, pp. 24-9.

121 'Introduction', D Porter (ed.), op. cit., note 70 above, p. 24.

${ }^{122} \mathrm{R}$ Porter, 'Taking histories, medical lives: Thomas Beddoes and biography', in Shortland and Yeo (eds), op. cit., note 2 above, pp. 216-17.
}

\footnotetext{
${ }^{123}$ Exceptionally, Dr W B Berry of Queenstown served on the Redwater Commission of 1883 that dealt with redwater fever, a very contagious but endemic cattle disease (D Gilfoyle, 'Veterinary science and public policy at the Cape Colony, 1877-1910', DPhil thesis, University of Oxford, 2002, p. 57).

${ }^{124}$ A467/88, address.
} 


\section{Anne Digby}

interventions. However, his concept of the general good was racially discriminatory; both as a doctor and as a Bond politician this was constructed within a cultural paradigm typical of a white male Cape citizen of his generation. Thus, whilst on the one hand he upheld the political liberty of whites through his opposition to permanent disfranchisement of Afrikaner "rebels", on the other, he was insensitive as a public health reformer to the fact that "good" — as determined by a white élite—was done to "coloured" or African individuals through the imposition of compulsory treatment regimes, regardless of any infringement of their human rights. ${ }^{125}$

${ }^{125}$ See E B van Heyningen, 'Cape Town and the plague of 1901', Studies in the history of Cape Town, vol. 4, Cape Town, University of Cape Town, History Workshop, 1984, pp. 66-107, for a discussion of the most extreme incident resulting from this kind of attitude in the forced removal of the African population in Cape Town to the Cape Flats following the outbreak of plague. 